\title{
Community development along a proglacial chronosequence: are above-ground and below-ground community structure controlled more by biotic than abiotic factors?
}

\author{
Matthew L. Carlson ${ }^{1}$, Lindsey A. Flagstad ${ }^{1}$, François Gillet ${ }^{2,3}$ and \\ Edward A. D. Mitchell $3,4,5 *$ \\ ${ }^{1}$ Alaska Natural Heritage Program and Biological Sciences Department, University of Alaska Anchorage, 707 A St., \\ Anchorage, AK 99501, USA; '2Laboratoire Chrono-Environnement, UMR 6249 CNRS, Université de Franche-Comté, \\ 16 route de Gray, 25030 Besançon Cedex, France; ${ }^{3}$ École Polytechnique Fédérale de Lausanne, Laboratory of \\ Ecological Systems, Station 2, CH-1015 Lausanne, Switzerland; ${ }^{4}$ Ecosystem Boundaries Research Unit, Wetlands \\ Research Group, WSL Swiss Federal Research Institute, Station 2, CH-1015 Lausanne, Switzerland; and ${ }^{5}$ Laboratory \\ of Soil Biology, Institute of Biology, University of Neuchâtel, $\mathrm{CH}-2009$ Neuchâtel, Switzerland
}

\section{Summary}

1. We studied vascular plant and soil-dwelling testate amoeba communities in deglaciated sites across a range of substrate ages in Kenai Fjords, Alaska, USA to test four hypotheses. (i) Patterns of community assembly are similar for vascular plants and testate amoebae. (ii) Vascular plant and testate amoeba communities are more strongly correlated to abiotic variables than to each other, since these communities are not directly linked trophically. (iii) Plant community structure becomes less associated with abiotic condition in succession relative to testate amoebae, as species replacement is believed to be more common for plants than testate amoebae. (iv) Above- and belowground communities become more strongly linked over the succession, due a shift from predominantly allogenic to autogenic forces.

2. We assessed relationships among biotic communities and abiotic site variables across the chronosequence using multiple factor analysis, redundancy analysis (RDA) and a moving-window analysis.

3. The diversity patterns and the communities' response to site and soil variables differed between groups. The composition of both communities was significantly explained by bedrock type and moisture regime. The vascular plant community, however, was more influenced by distance from the glacier.

4. Testate amoeba and vascular plant community patterns were significantly linked to each other and to location and physical conditions. The moving-window RDA indicates the variation explained by the physical and chemical environment tended to slightly decrease through the chronosequence for testate amoebae, while a bell-shape response was evidenced for vascular plants. The variation of the microbial community explained by the plant community was very low in the early stages of the succession and became higher than the variation explained by the environmental variables later in the chronosequence.

5. Synthesis. These results suggest that vascular plants and testate amoebae are as linked or more in ecosystem development than either community is to changes in site condition. Furthermore, the strength of interactions varies along the succession. Thus, ecological links may be more important than macro-scale abiotic site condition is to community development, even between communities without direct trophic interactions.

Key-words: Alaska, community ecology, determinants of plant community diversity and structure, glacier, primary succession, testate amoebae, vascular plants 


\section{Introduction}

Understanding interactions among communities is a major challenge in ecology (Wardle 2002) and studies of community patterning across spatial environmental gradients or temporal successional series are useful in suggesting possible mechanisms and interactions (Cutler, Belyea \& Dugmore 2008; Mahaming, Mills \& Adl 2009). Diversity patterns of organisms are usually well correlated over short ecological gradients, but such correlations often break down when studies are extended across broader gradients of space or time (Prendergast et al. 1993; Scheu \& Schulz 1996; De Deyn \& Van der Putten 2005; Kardol et al. 2005; Kardol, Bezemer \& van der Putten 2006). Broad inter-taxon or inter-functional group diversity correlations are thought to exist (i) if one group directly controls the status of the other group, (ii) if one group indirectly controls the status of the other group through relationships with other biota, or (iii) if both groups are dependent on the same abiotic control (e.g. climate). Traditional community ecological theory proposes that abiotic conditions drive species diversity (Odum 1971; Gough et al. 2000). Correlations between species groups, observed in studies of environmental gradients or succession, therefore, should be traceable to underlying abiotic control factors. However, there is little consensus as to what this underlying control factor might be (Huston \& Smith 1987). The failure to develop a unifying theory of determinate and predictable plant succession turned attention to stochastic and neutral models (Connor \& Simberloff 1979; Fastie 1995; Hubbell 2001) and, more recently, to biotic interactions between above-ground and below-ground communities as important community assembly and ecosystem development structuring mechanisms (De Deyn et al. 2003; Wardle, Walker \& Bardgett 2004; Kardol, Bezemer \& van der Putten 2006).

Terrestrial plants and soil organisms are physically linked through the soil medium and functionally linked through their mutual and bidirectional effects on soil fertility (Wardle, Walker \& Bardgett 2004). Plant communities contribute resources through litterfall and rhizodeposition (root exfoliates and exudates) to below-ground organisms. Below-ground organisms promote plant growth by converting the minerals immobilized in plant biomass and soil organic matter to chemical forms that plant roots are able to assimilate (Clarholm 1985; Bonkowski 2004). Plant diversity theoretically controls the diversity of decomposer organisms through biomass inputs that vary in quantity, quality and structure (Ledeganck, Nijs \& Beyens 2003); conversely the diversity of the decomposer community controls plant diversity by providing a variety of mineralized nutrients that are differentially useful to, and thus partitioned among, the plant community (Hooper et al. 2000; Reynolds et al. 2003; Harrison, Bol \& Bardgett 2007). Thus, the mechanistic link between plants and much of the soil biota is expected to be indirect. The nature of these linkages is thought to drive succession. For example, negative feedback, where the activity of a plant species creates an environment increasingly adverse to its growth and reproduction would facilitate species replacements, thereby promoting belowground species turnover (Wardle 2002). Alternatively, positive feedback, where the activity of a plant species creates an environment that benefits its growth and reproduction would retard successional processes by prolonging the residence of dominant plant species (De Deyn et al. 2003; Bardgett et al. 2005) and below-ground biota associated with that environment.

Community assembly in early succession depends on the inherent size of the species pool (Weiher \& Keddy 1999) and the dispersal potential of the organisms, which varies among taxonomic and functional groups. Microorganisms are generally assumed to not be limited by dispersal because of their small individual size and huge population size (but see Foissner 2007). The assembly of soil protozoa communities in early primary succession has been shown to follow a pattern of successive addition, rather than species replacement (Wanner et al. 2008). This contrasts with vascular plant primary successional patterns for which species turnover characterizes community assembly (Reiners, Worley \& Lawrence 1971; Matthews \& Whittaker 1987). This is in part due to differential space limitations on plants and soil microorganisms. Plants occupy planar space, whereas soil microorganisms occupy a complex threedimensional space that allows greater species packing. Unlike microorganisms, dispersal of vascular plants is expected to vary considerably by species at the scale of tens to hundreds of meters. Seed dispersal is a function of the number and distribution of reproductive individuals, their fecundity and seed shadows (Nathan \& Muller-Landau 2000), which clearly vary by species. While most species have colonization rates of only a few metres per year, some early colonizing species are capable of much greater dispersal distances (cf. Cain, Milligan \& Strand 2000 and references therein). Another difference between the two groups of organisms is their sensitivity to drought: while the establishment of vascular plants in early succession stages is partly limited by drought stress (Jones \& del Moral 2009), many microorganisms (e.g. testate amoebae) are able to survive unfavourable conditions by encysting. It follows that plants may be expected to be controlled primarily by abiotic factors and dispersal limitations in early developmental stages and increasingly by biotic interactions in later stages, while for soil microbes the influence of abiotic conditions and biotic interactions on community structure may be expected to only become apparent when communities saturate with respect to species abundance and diversity.

Our aims were to describe the nature of above-ground and below-ground community change in primary succession in relation to site variables along a proglacial chronosequence in south-central Alaska, USA. Specifically, we tested four predictions, based on successional ecological theory, but focused on above-ground-below-ground interactions. Because of the strong changes in ecosystem characteristics, including changes in both abiotic (e.g. micro-climate) and biotic (e.g. food-web complexity) factors, we predict that (i) the patterns of species richness, evenness, diversity and community assembly are similar for plants and soil microbes (specifically the protozoa, testate amoebae). Because plants and soil protozoa are not directly linked trophically, we expect that (ii) vascular plant and soil protozoan communities are less correlated to each other 
than they are to abiotic variables. We predict that (iii) correlations between soil protozoan communities and abiotic site conditions will increase in succession; due to the additive assembly pattern of soil protozoa, early communities are more likely to be random assemblages and when the full potential diversity of the community has been reached in the later stages, relationships are more likely to be detectible. (iv) Correlations between abiotic site conditions and plant community structure are expected to decline during succession. This decline is predicted because of the successive assembly pattern of vascular plants: as the vegetation cover increases, species turnover, and thus biotic interactions, increase, thus reducing the relative influence of abiotic factors. Because of direct or indirect interactions or because both plant and soil protozoan communities are influenced in a similar way by changing abiotic factors (even if these factors play a decreasing role in plant communities), we anticipate that (v) the correlation between above- and below-ground communities will increase across the chronosequence.

We selected testate amoebae, a group of soil protozoa, as a proxy for below-ground biota over other soil organism groups because they: (i) characterize the overall microbial community due to their relatively high trophic position, (ii) represent an important part of the biomass of soil organisms, (iii) are functionally important, (iv) ecologically sensitive, (v) ubiquitous and (vi) relatively easy to sample and identify (Mitchell, Charman \& Warner 2008). Soil protozoa are much less studied than other microbial groups such as bacteria, fungi and nematodes despite their recognized importance to terrestrial ecosystems both in terms of biomass and nutrient cycling (Clarholm 2005; Adl \& Gupta 2006; Wilkinson 2008). Among the different groups of soil protozoa, testate amoebae stand out as being functionally important for C, N and Si cycling (Schönborn 1992; Schröter, Wolters \& De Ruiter 2003; Aoki, Hoshino \& Matsubara 2007). Testate amoebae respond strongly to soil type, moisture regime and water chemistry causing their density and community structure to change clearly across spatial and temporal ecological gradients (Bonnet 1961, 1964; Lousier 1974; Foissner 1987; Mitchell, Charman \& Warner 2008). Unlike other soil protozoa, testate amoebae produce a shell (test) that allows identification to species level using nonmolecular methods. Testate amoeba and plant communities are expected to interact indirectly through the soil microbial loop and in response to similar abiotic factors. This combination of characteristics makes testate amoebae a useful model group for studies on soil ecology and of above-ground-belowground relationships.

\section{Materials and methods}

\section{STUDY AREA}

Kenai Fjords is a dynamic glacial landscape located in the maritimeboreal ecoregion of south-central Alaska, USA. In the period postdating the Little Ice Age maximum (c. $1850 \mathrm{AD}$ ) most tidewater glaciers in Kenai Fjords receded (Wiles \& Calkin 1994). The most impressive example of this glacial recession is the 20-km retreat of the McCarty Glacier over a 55-year period (Wiles \& Calkin 1993). The terrains exposed by the recession of the McCarty Glacier comprise a proglacial chronosequence with good chronological control across which patterns of primary succession can be investigated.

Sites for vegetation and testate amoeba survey were selected to capture differently aged terrains and their associated biotic communities. Terrains closest to the glacier are barren or sparsely vegetated. With increasing distance from the glacier the plant community transitions from Alnus viridis ssp. sinuata and Alnus viridis ssp. sinuata-Salix sitchensis shrublands to Picea sitchensis and Tsuga mertensiana forests, to peatlands (Fig. 1 and see Flagstad 2007). Initially 16 sites were selected; 15 of which are located along the length of McCarty Fjord. An additional site was added from the adjacent Northwestern Fjord (similar spatial-orographic orientation and bedrock type) so that one of the oldest common plant community types in the landscape, a Carex-Sphagnum-dominated peatland, could be represented. Descriptions of primary characteristics of the sites are given in Table 1. All fieldwork was conducted in summer 2005.

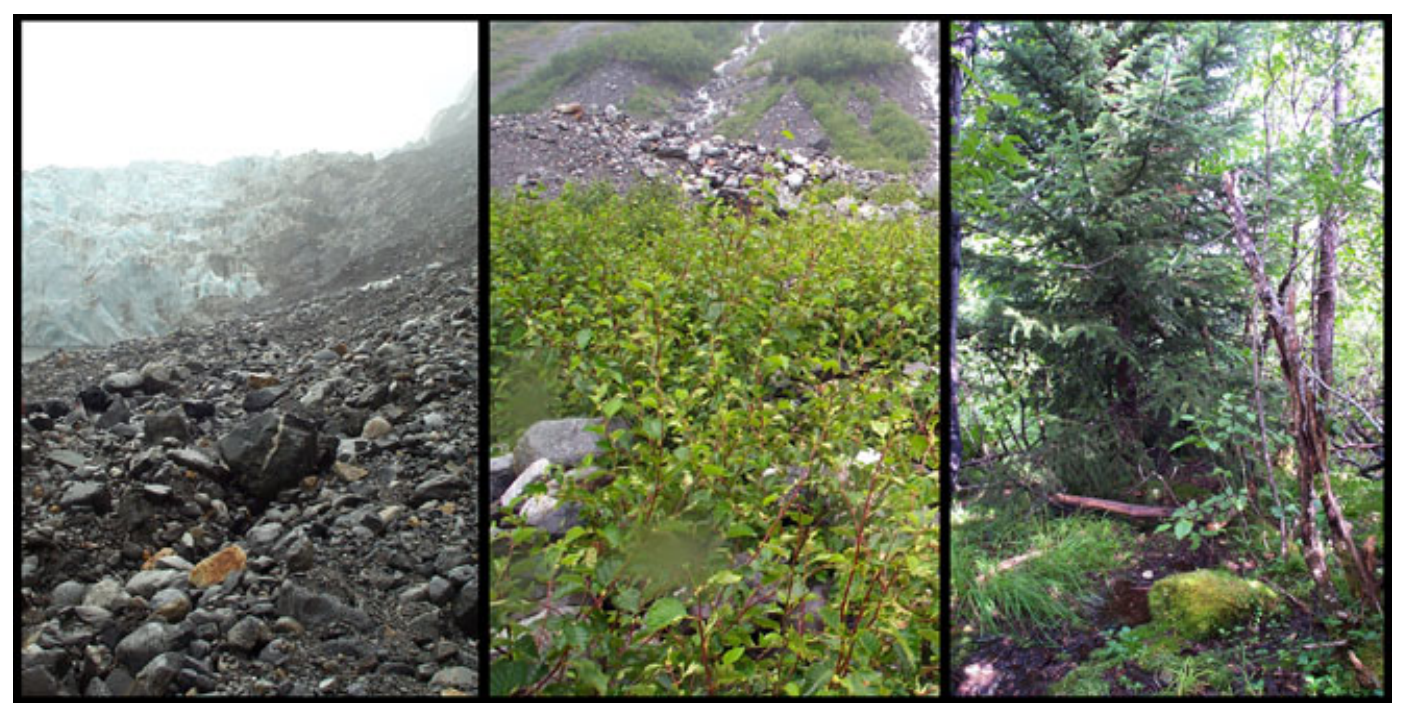

Fig. 1. Three representative sites along the McCarty Fjord chronosequence. Left: barren close to the glacier front (c. 5 years since deglaciation); centre: low alder scrub (c. 25 years); right: young coniferous forest (c. 50 years). 
Table 1. Summary of characteristics for sites sampled in Kenai Fjords, Alaska, USA. Distances from the glacier were measured using the digital measurement tool in ArcMap (Environmental Systems Research Institute Inc 2006). The distance measurements for sites 1-15 are taken from the year 2000 terminus of the McCarty Fjord glacier. Terrains were dated by a combination of bathymetry (Post 1980), historic aerial photography (Crowell \& Mann 1995; Environmental Systems Research Institute Inc 1998; National Park Service 2002) and dendrochronology (Flagstad 2007). Substrate types were taken from the geological map authored by Bradley et al. (1999). Plant and testate amoebae communities were defined by cluster analysis using PC-ORD

\begin{tabular}{|c|c|c|c|c|c|}
\hline $\begin{array}{l}\text { Site } \\
\text { number }\end{array}$ & $\begin{array}{l}\text { Distance } \\
\text { from } \\
\text { glacier }(\mathrm{km})\end{array}$ & $\begin{array}{l}\text { Estimated } \\
\text { terrain } \\
\text { age (years) }\end{array}$ & Substrate type & Plant community type & $\begin{array}{l}\text { Testate amoeba community } \\
\text { type }\end{array}$ \\
\hline 1 & 0.2 & $0-5$ & Metasedimentary & Depauperate & Depauperate \\
\hline 2 & 0.6 & $0-5$ & Metasedimentary & Open Alder & Corythion dubium \\
\hline 3 & 0.8 & $0-5$ & Metasedimentary & Open Alder & $\begin{array}{l}\text { Centropyxis aerophila-Trinema } \\
\text { complanatum }\end{array}$ \\
\hline 4 & 3.5 & $56-64$ & Metasedimentary & Closed Tall Alder-Willow & Corythion dubium \\
\hline 5 & 5.7 & $56-64$ & Metasedimentary & Closed Tall Alder-Willow & $\begin{array}{l}\text { Centropyxis aerophila-Trinema } \\
\text { complanatum }\end{array}$ \\
\hline 6 & 8.3 & $56-64$ & Metasedimentary & Open Alder & Corythion dubium \\
\hline 7 & 8.4 & $56-64$ & Metasedimentary & Closed Tall Alder-Willow & Corythion dubium \\
\hline 8 & 11.0 & $56-64$ & Metasedimentary & Closed Tall Alder-Willow & Corythion dubium \\
\hline 9 & 11.2 & $56-64$ & Metasedimentary & Closed Tall Alder-Willow & Corythion dubium \\
\hline 10 & 12.9 & $56-64$ & Metasedimentary & Closed Tall Alder-Willow & Corythion dubium \\
\hline 11 & 21.8 & $80-146$ & Metasedimentary & Closed Spruce & Corythion dubium \\
\hline 12 & 22.3 & $80-146$ & Metasedimentary & Closed Spruce & $\begin{array}{l}\text { Centropyxis aerophila-Trinema } \\
\text { complanatum }\end{array}$ \\
\hline 13 & 30.4 & $>146$ & Granitic & Open Hemlock & Quadrulella symmetrica \\
\hline 14 & 30.5 & $>146$ & Granitic & Wetland & Quadrulella symmetrica \\
\hline 15 & 30.6 & $>146$ & Granitic & Open Hemlock & $\begin{array}{l}\text { Centropyxis aerophila-Trinema } \\
\text { complanatum }\end{array}$ \\
\hline 16 & NA & $>146$ & Granitic & Wetland & Quadrulella symmetrica \\
\hline
\end{tabular}

Distances from the glacier to sampling locations were measured using ArcMap (Environmental Systems Research Institute Inc 2006). The distance measurements for sites 1-15 are taken from the year 2000 terminus of the McCarty Fjord Glacier. Bedrock type was inferred from the geologic maps of the Seldovia, Seward and Blying Sound Quadrangles (Tysdal \& Case 1979; Bradley et al. 1999).

\section{SOIL DESCRIPTION AND ANALYSES}

The soil profile, including depth of the organic horizon, was described to a depth of $30 \mathrm{~cm}$ at each site. Soil samples $(0-10 \mathrm{~cm}$ depth) were collected to survey testate amoeba survey and for physical and chemical analysis at each site. Soil samples were aggregated from three subsamples ( $>2 \mathrm{~m}$ apart) that were located within the dominant groundcover. The percentage dry weight of coarse $(>0.075 \mathrm{~mm}$ minimum diameter) and fine ( $<0.075 \mathrm{~mm}$ minimum diameter) fraction of each soil sample was determined. The fine fraction was analysed for $\mathrm{pH}$ from a 1:1 slurry preparation, total organic $\mathrm{C}$ and total $\mathrm{N}$ were determined using combustion analysis of the fine fraction, and available nitrogen $\left(\mathrm{NH}_{4}{ }^{+}, \mathrm{NO}_{3}^{-}\right), \mathrm{Na}, \mathrm{Mg}, \mathrm{P}, \mathrm{K}, \mathrm{Ca}, \mathrm{Mn}, \mathrm{Fe}, \mathrm{Cu}$ and $\mathrm{Zn}$ were determined by inductively coupled plasma emission spectroscopy at the University of Alaska Fairbanks, Palmer Research Center Soils Laboratory.

\section{VEGETATION SURVEYS}

At each site all vascular plant species growing in a $10 \times 10 \mathrm{~m}$ plot were identified. Non-vascular plants were also recorded, but because not all taxa were identified to species or generic levels at all sites, we do not include these data in our analysis. Percentage cover for each plant species and type of unvegetated groundcover (e.g. rock, sand, litter, wood) were estimated for each plot. The few vascular plants not identifiable to species level were identified by genus. At two sites, a non-reproductive forb and a grass were not identifiable to genus and were identified by life-form. See Appendix S1 in Supporting Information for a complete description of plant community types; additional information can be found in Flagstad (2007).

\section{TESTATE AMOEBA ANALYSES}

Samples were prepared for the testate amoeba survey following a modification of the stepwise filtration method of Hendon \& Charman (1997). Air-dried samples were shaken with $40 \mathrm{~mL}$ of deionized water for $1 \mathrm{~min}$. Slides were surveyed for testate amoebae in grid fashion using light microscopy at $400 \times$ magnification under phase contrast. One or more slides were systematically scanned for a standardized total of $6 \mathrm{~h}$ of survey effort per sample. Numbers of all species were recorded. Appendix S2 gives a complete description of testate amoeba community types; see Flagstad (2007) for more information.

\section{NUMERICAL ANALYSIS}

The site nearest to the glacier was excluded from the analysis because no testate amoebae were recorded. We first compared the patterns of species richness, evenness and Shannon's diversity of vascular plant and testate amoeba communities along the chronosequence. Evenness was calculated as the Hill's ratio of Shannon's diversity to species richness (Hill 1973). To assess monotonic relationships, the Spearman's rank correlation between diversity indices of the two communities was tested, as well as between these indices and the distance to the glacier and the age class. 
Multiple factor analysis (MFA) was used to symmetrically link five groups of descriptors: the two Hellinger-transformed community data sets (vascular plants and testate amoebae) and three groups of abiotic variables describing site location (distance from glacier, age class, bedrock type, elevation, slope and aspect), physical (percentage cover of litter, wood, sand and rock, moisture regime, percentage dry weight of fine material, thickness of the organic horizon) and chemical soil conditions $\left(\mathrm{pH}, \mathrm{NH}_{4}, \mathrm{NO}_{3}\right.$, total $\mathrm{C}, \mathrm{N}, \mathrm{P}, \mathrm{K}, \mathrm{Ca}, \mathrm{Mg}, \mathrm{Na}, \mathrm{Cu}$, $\mathrm{Zn}, \mathrm{Mn}, \mathrm{Fe}$ ). Multiple factor analysis was chosen among the variety of symmetric ordination methods that are available for linking ecological data tables (Dray, Chessel \& Thioulouse 2003) because it allows the simultaneous coupling of several groups or subsets of variables defined on the same objects (Escofier \& Pagès 1994). Multiple factor analysis is a simple variant of co-inertia analysis, which seeks the common structures present in all or some of these subsets. As this method, mainly used in sensory evaluation and chemistry so far, with the exception of one ecological study (Lamentowicz et al. 2010), is not familiar to ecologists, we provide a brief summary of its principles.

If all variables are numerical, then MFA is basically a principal component analysis (PCA) applied to the whole set of variables in which each subset is weighted. The use of weights balances inertia between the different groups and thus balances their influences. Multiple factor analysis is performed in two steps. First, a PCA is performed on each subset, which is then normalized by dividing all its elements by the first eigenvalue obtained from its PCA. Secondly, the normalized subsets are merged to form a unique matrix and a global PCA is performed on this matrix. The individual subsets are then projected onto the global analysis to analyse communalities and discrepancies. The similarity between the geometrical representations derived from each group of variables is measured by the RV coefficient, ranging from 0 to 1 (Robert \& Escoufier 1976). RV coefficients can be tested by permutations (Josse, Pagès \& Husson 2008). Euclidean distances between site scores in the MFA were used to perform a cluster analysis with the Ward method. This allows discovering the main discontinuities in the structure of the data described by all biotic and abiotic subsets of variables.

The ordination patterns of vascular plant and testate amoeba communities and their causal relationships to environmental variables were assessed using redundancy analysis (RDA) after Hellinger transformation of each community data set. Hellinger transformation is one of the pre-transformation of species data proposed by Legendre \& Gallagher (2001) to allow using RDA without considering the common absence of the species as a resemblance between communities. It is computed as the square root of the relative abundance per site. A forward selection of explanatory variables among the whole set of site and soil variables was computed for each community data set using the 'ordistep' function available in the vegan $\mathrm{R}$ package (Oksanen et al. 2010). This function achieves automatic stepwise model building for constrained ordination methods, using AIC and permutation tests.

To evaluate change in the causal relationships between biotic communities and soil variables across the chronosequence a moving-window analysis was performed. Moving-window techniques allow the analysis of multivariate data across a gradient (Legendre \& Legendre 1998) and are particularly useful for the detection of sharp transitions in species composition (Kent et al. 1997). Moving-window analysis was computed from a reduced sample of 10 consecutive sites. The 10sample window was advanced across the chronosequence one sample at a time to quantify and to test the variation of each community matrix explained by soil variables over successional time. Redundancy analyses, adjusted $R^{2}$ and permutation tests were used to assess the relationships (Legendre, Borcard \& Peres-Neto 2005). The response matrices were the two Hellinger-transformed community matrices, and the explanatory matrices contained a selection of standardized physical and chemical variables (location variables were excluded). The computation of adjusted $R^{2}$ from RDA after a forward selection of explanatory variables within each window would be likely to give inconsistent results because the identity and number of selected explanatory variables may be different along the sequence. Therefore, we used the same regression model for physical-chemical environment within every window, based on a preliminary forward selection of explanatory variables for the whole sequence. Additionally, we tested the indirect causal relationship between the microbial community and the plant community. We used the first three principal components of separate PCAs as explanatory variables in the vascular plant species data set due to the high numbers of species.

All computations were performed with R 2.10.1 (R Development Core Team 2009) using vegan (Oksanen et al. 2010) and FactoMineR (Lê, Josse \& Husson 2008; Husson et al. 2009) packages.

\section{Results}

\section{PATTERNS OF VASCULAR PLANT AND TESTATE AMOEBA SPECIES RICHNESS, EVENNESS AND SHANNON DIVERSITY}

Patterns of vascular plant and testate amoeba species richness, evenness and Shannon diversity differ along the McCarty Fjord chronosequence (Figs 2 and 3). No significant monotonic relationship was found with distance to the glacier or site age (Table 2).

Vascular plant species richness is highest (c. 30 taxa) in the oldest sites, while for testate amoebae the pattern suggests an early increase to maximum levels (c. 15 taxa) followed by a slight decline to about 10 taxa. High testate amoeba species richness is, however, also observed in the oldest (peatland) site.

Vascular plant evenness increases sharply from young to intermediate-aged sites then declines again in older sites. The pattern is different for testate amoebae with evenness values ranging between 0.6 and 0.9 across the chronosequence with no detectable trend.

Vascular plant Shannon diversity increases sharply from early to intermediate-ages sites as for species richness, but in contrast to species richness, highest values are reached in intermediate-aged and not the oldest sites. The pattern observed for testate amoebae was very similar to that of vascular plants, but the correlation between the two was nevertheless not significant when a Holm correction was applied (Table 2).

\section{RELATIONSHIPS BETWEEN BIOTIC COMMUNITIES AND SITE VARIABLES}

The separate RDAs show somewhat contrasting species-environment relationships for vascular plants and testate amoebae (Fig. 4). In both analyses, the first two axes were significant. For vascular plants (Fig. 4a) four explanatory variables were selected, which explain $45.9 \%$ of the variance (adjusted $R^{2}$ ). For testate amoebae (Fig. 4b) the best model includes four 
(a)
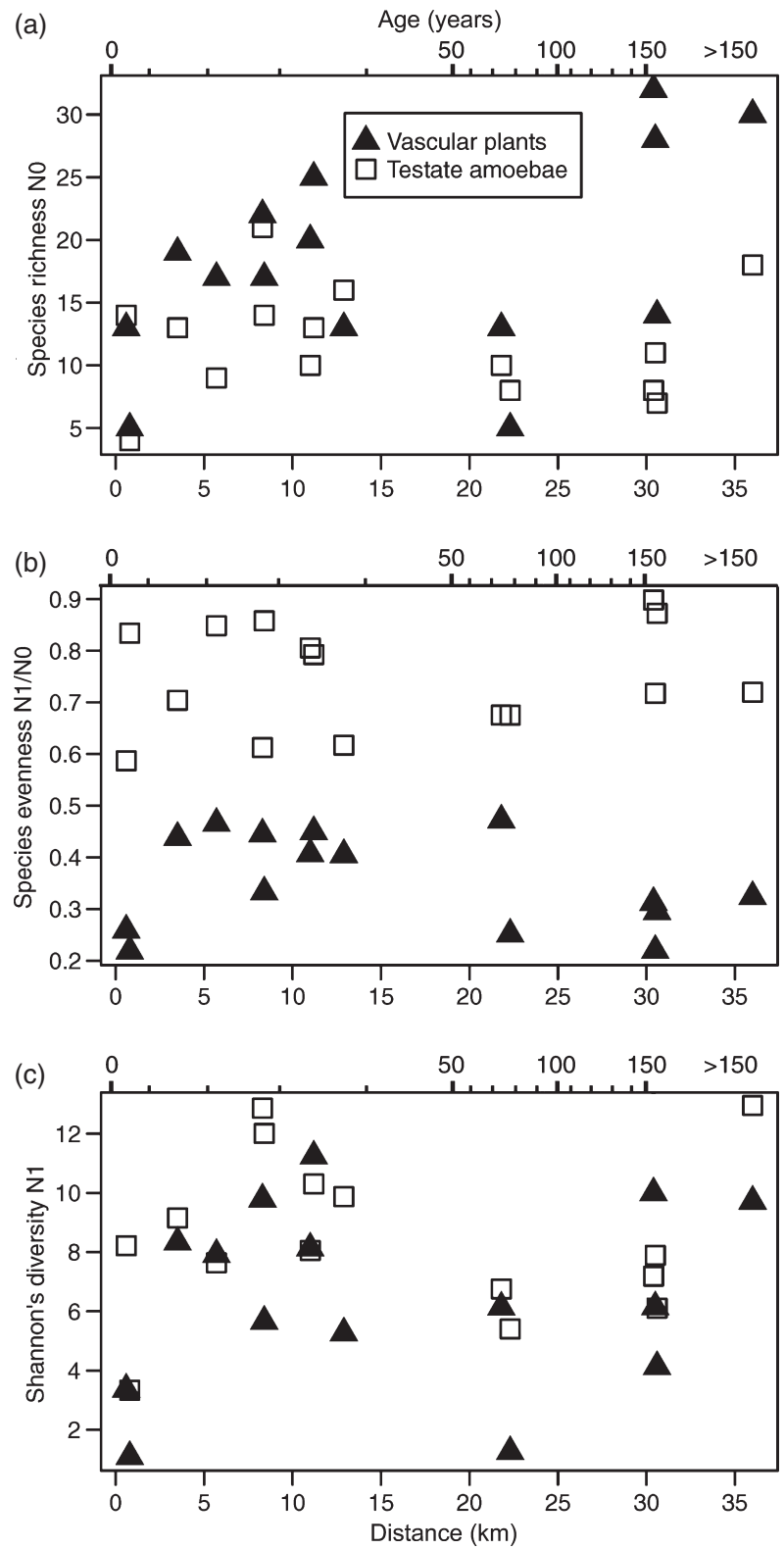

Fig. 2. Comparison of vascular plant (solid triangles) and testate amoeba (open squares) species richness (a), species evenness (b) and Shannon's diversity (c) along the McCarty Fjord chronosequence, Kenai Fjords, Alaska, USA.

explanatory variables with only $26.8 \%$ of explained variation. The testate amoeba and vascular plant data sets are both related to bedrock type and moisture regime. In addition, vascular plants are also related to distance to the glacier and percentage cover of bare soil, while testate amoebae are also related to soil zinc content and percentage cover of rock.

The vascular plant and testate amoeba RDAs also differ with respect to the relative position of sites in the ordination space. Two groups emerge for vascular plants (Fig. 4a): a welldefined group composed of the early to intermediate aged sites (2-10) and a second, looser group composed of older sites (1116) (or two sub-groups with mid-seral forested sites 11 and 12 ,

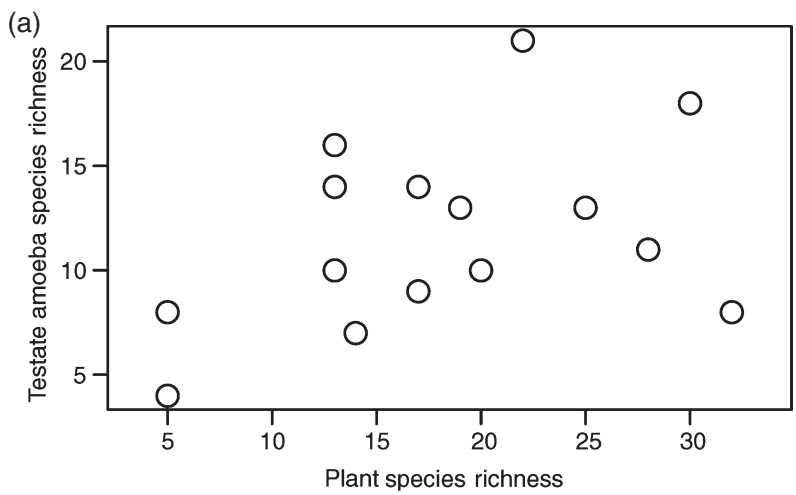

(b)

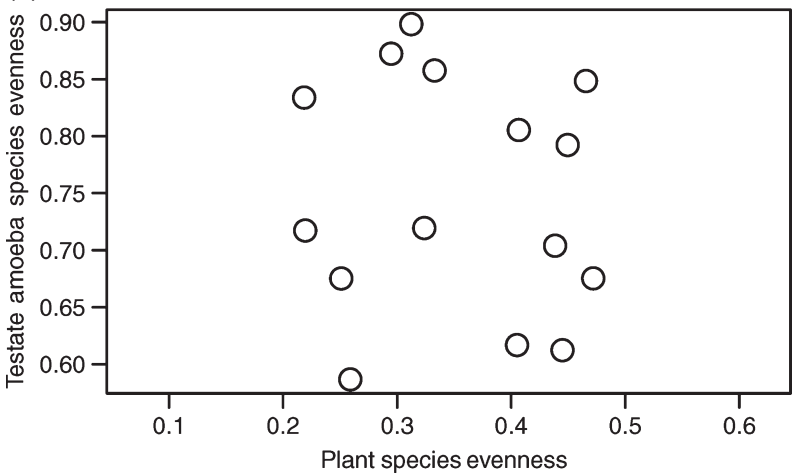

(c)

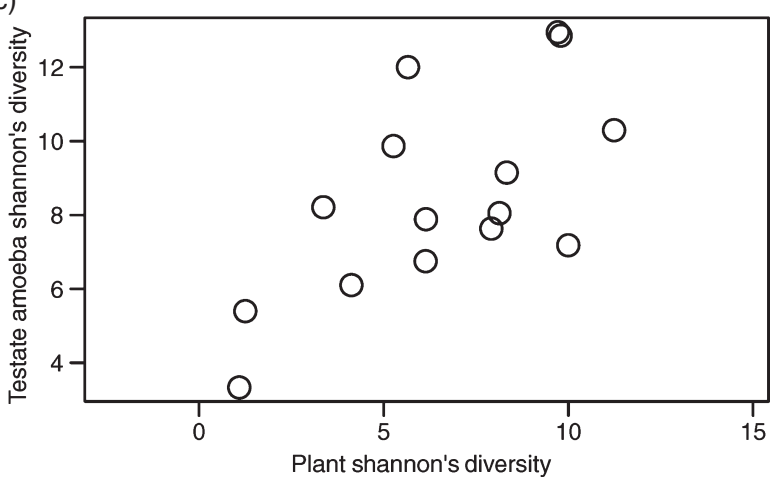

Fig. 3. Relationship between vascular plant and testate amoeba species richness (a), species evenness (b) and Shannon's diversity (c) in the McCarty Fjord chronosequence, Kenai Fjords, Alaska, USA.

separate from late-seral forests and peatlands along axis 2). For testate amoebae (Fig. 4b), another pattern emerges, in which early and late-successional sites are not as clearly separated. Nevertheless, taken together in the MFA, the two biotic and three environmental data sets suggest a division of sites into two groups corresponding to the early sites (2-10) and late sites (11-16) (Fig. 5). The MFA ordination shows that the first group is more heterogeneous than the second, mainly because of the position of site 3 .

The patterns of species-environment relationships are further illustrated by the RV coefficients (Table 3). The composition of testate amoeba and vascular plant communities is significantly linked to location and physical conditions, but not to chemical variables. Vascular plants and testate amoebae are also significantly linked. Among abi- 
Table 2. Rank correlation between vascular plants and testate amoeba species richness, evenness, Shannon's diversity, distance from the glacier and age class in McCarty Fjord chronosequence, Kenai Fjords, Alaska, USA. Below diagonal (bottom-left half of the matrix): Spearman's correlation, above diagonal: Holm-corrected $P$-value. Significant correlations appear in bold

\begin{tabular}{lrrrr}
\hline & $\begin{array}{c}\text { Vascular } \\
\text { plants }\end{array}$ & $\begin{array}{l}\text { Testate } \\
\text { amoebae }\end{array}$ & Distance & \multicolumn{1}{c}{$\begin{array}{l}\text { Age } \\
\text { class }\end{array}$} \\
\hline Species richness $N_{0}$ & & & & \\
$\quad$ Vascular plants & 1.000 & 0.734 & 0.650 & 0.420 \\
Testate amoebae & 0.319 & 1.000 & 1.000 & 1.000 \\
Distance & 0.379 & -0.100 & 1.000 & $<\mathbf{0 . 0 0 1}$ \\
Age class & 0.460 & -0.172 & $\mathbf{0 . 9 3 7}$ & 1.000 \\
Species evenness $E_{1}=$ & $N_{1} / N_{0}$ & & & \\
Vascular plants & 1.000 & 1.000 & 1.000 & 1.000 \\
Testate amoebae & -0.079 & 1.000 & 1.000 & 1.000 \\
Distance & -0.164 & 0.239 & 1.000 & $<\mathbf{0 . 0 0 1}$ \\
Age class & -0.120 & 0.291 & $\mathbf{0 . 9 3 7}$ & 1.000 \\
Shannon's diversity & $N_{1}$ & & & \\
Vascular plants & 1.000 & 0.161 & 1.000 & 1.000 \\
Testate amoebae & 0.561 & 1.000 & 1.000 & 1.000 \\
Distance & 0.179 & -0.057 & 1.000 & $<\mathbf{0 . 0 0 1}$ \\
Age class & 0.257 & -0.126 & $\mathbf{0 . 9 3 7}$ & 1.000 \\
\hline
\end{tabular}

otic variables, location and chemical variables are both only linked to the physical variables, but not to each other. Contrary to expectations (hypothesis 2), plant and testate amoeba patterns display a much tighter relationship to each other than they do to the patterns describing physical and chemical soil condition.

\section{CAUSAL RELATIONSHIPS AMONG VEGETATION, TESTATE AMOEBAE AND SOIL VARIABLES ALONG THE CHRONOSEQUENCE: MOVING-WINDOW ANALYSIS}

Three variables were retained by stepwise selection to build the two species-environment regression models used in the moving-window analysis: moisture regime, soil zinc content and percentage cover of rock for the testate amoeba community and depth of soil organics, soil $\mathrm{pH}$ and percentage cover of bare soil for the vascular plant community. To test the response of testate amoebae to vegetation, we selected the same number of explanatory variables, i.e. the weighted-average site scores along the three-first axes of the PCA of the Hellinger-transformed vegetation table.

Interestingly, and contrary to our third hypothesis, the moving-window analysis shows that the dependence of the testate amoeba community to soil condition tends to decline after the early successional stages, while a bell-shape response, peaking across the mid-successional stages is evidenced for the vascular plant community (Fig. 6). Furthermore, in agreement with hypothesis 4 , the variation of the microbial community explained by the plant community was very low in the early stages of the succession and became higher than the variation explained by the environmental variables later in the chronosequence.
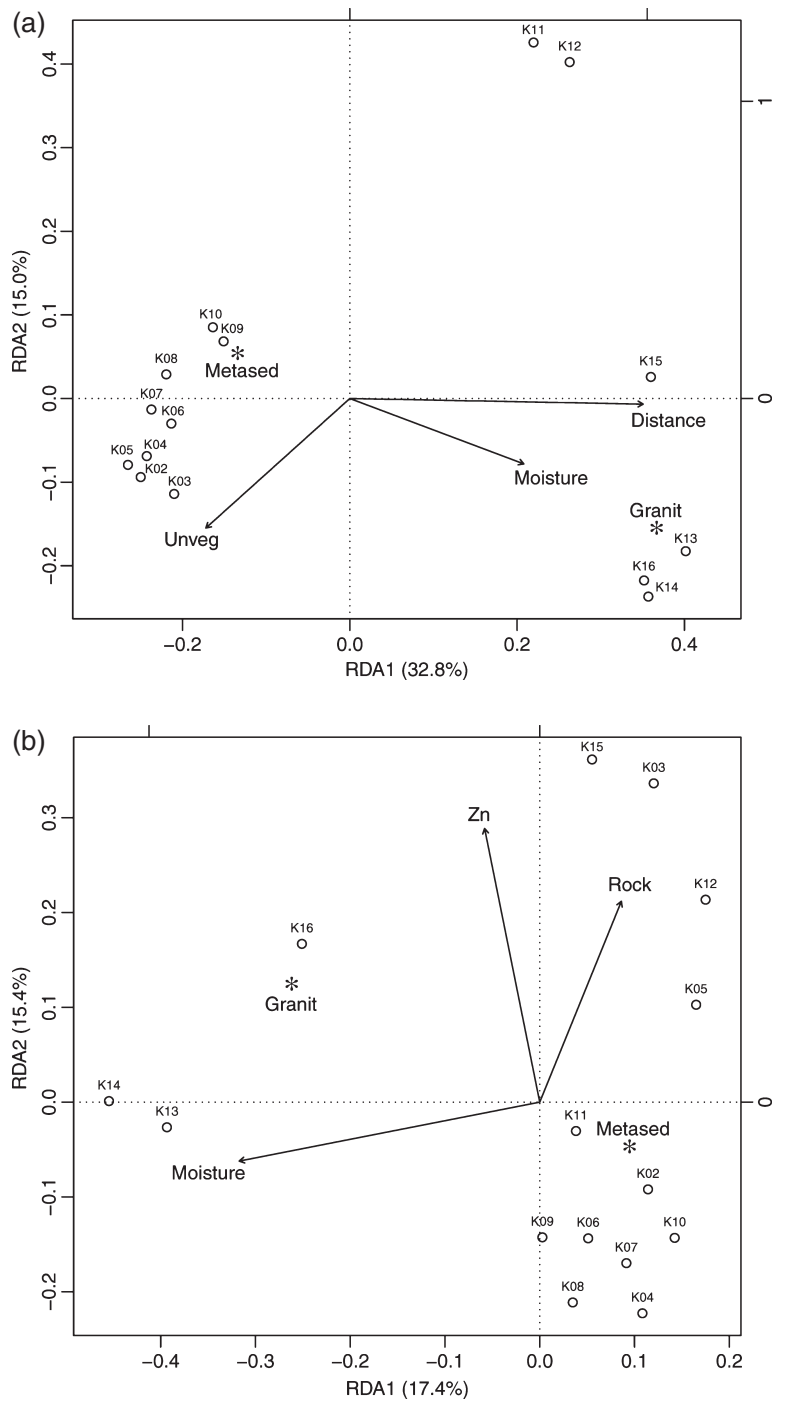

Fig. 4. Redundancy analysis plots of vascular plant (a) and testate amoeba (b) Hellinger-transformed species data constrained by environmental soil variables from the McCarty Fjord chronosequence, Kenai Fjords, Alaska, USA. Environmental variables retained after model selection are represented by vectors (arrows for quantitative or semi-quantitative variables) or centroids (asterisk for each level of a qualitative variable): Moisture: Moisture regime derived from plant community composition in accordance with Viereck et al. (1992); Distance: Distance (in $\mathrm{km}$ ) between the site and the position of the glacier in 2000; Bedrock: Granitic [Granit] or metasedimentary [Metased] bedrock type inferred from the geologic maps (Tysdal \& Case 1979; Bradley et al. 1999); Unveg: Percentage of unvegetated ground cover; Rock: Percentage cover of mineral material $>2 \mathrm{~mm}$ minimum dimension; Zn: Soil concentration of Zinc [p.p.m.]. Sites are indicated with a $\mathrm{K}$ followed by a number; lower numbers are sites closer to the glacier.

\section{Discussion}

PATTERNS OF PLANT AND TESTATE AMOEBA SPECIES RICHNESS, DIVERSITY AND EVENNESS

The patterns of increase in plant and testate amoeba species richness and diversity from newly exposed terrains to those more than 150 years old (i.e. not affected by the last glacial 


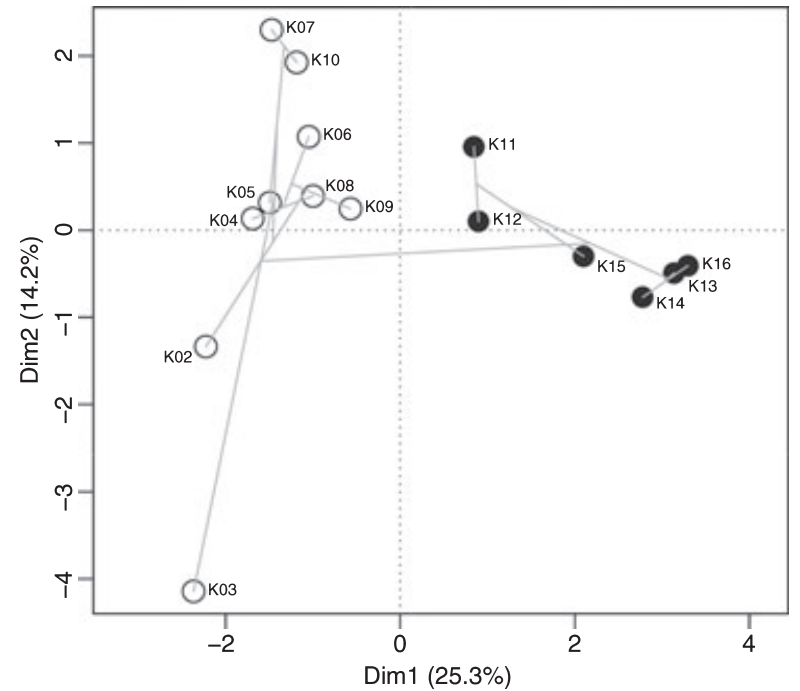

Fig. 5. Multiple factor analysis of the five community (vascular plants and testate amoebae, Hellinger-transformed) and environmental (location, soil physical and chemical variables, standardized) data sets from the McCarty Fjord chronosequence, Kenai Fjords, Alaska, USA. Projection of the multiple factor analysis (MFA) axes 1 and 2 with the result of a hierarchical agglomerative clustering (grey lines), obtained by the Ward method on the Euclidean distance matrix between MFA site scores, showing two main groups of sites (symbols). Sites are indicated with a K followed by a number; lower numbers are sites closer to the glacier.

Table 3. RV coefficients (below diagonal - bottom-left half of the matrix) and corresponding $P$-values (above diagonal) among the five groups of variables used in the multiple factor analysis of the McCarty Fjord chronosequence, Kenai Fjords, Alaska, USA. Significant coefficients appear in bold

\begin{tabular}{|c|c|c|c|c|c|}
\hline & $\begin{array}{l}\text { Testate } \\
\text { amoebae }\end{array}$ & $\begin{array}{l}\text { Vascular } \\
\text { plants }\end{array}$ & Location & Physical & Chemical \\
\hline $\begin{array}{l}\text { Testate } \\
\text { amoebae }\end{array}$ & 1.000 & $<0.001$ & 0.002 & 0.007 & 0.071 \\
\hline $\begin{array}{l}\text { Vascular } \\
\text { plants }\end{array}$ & 0.705 & 1.000 & $<0.001$ & 0.001 & 0.120 \\
\hline Location & 0.585 & 0.706 & 1.000 & $<0.001$ & 0.211 \\
\hline Physical & 0.546 & 0.550 & 0.588 & 1.000 & 0.027 \\
\hline Chemical & 0.479 & 0.395 & 0.326 & 0.419 & 1.000 \\
\hline
\end{tabular}

advance of $c$. 1850) shown in this study are consistent with general patterns of plant community development from primary substrates (Reiners, Worley \& Lawrence 1971; Matthews \& Whittaker 1987; del Moral \& Bliss 1993) and are generally supported for the primary succession of testate amoebae in proglacial (Hodkinson, Coulson \& Webb 2004) and other systems (Wanner \& Xylander 2005). However, contrary to our first prediction, the assembly of the two functionally different communities did not translate into similar patterns of species richness and evenness. The only significant relationship observed was between vascular plant and testate amoeba Shannon diversity, suggesting that the biotic and abiotic factors that affect the species richness and evenness of the two biotic groups influence species diversity to a lesser degree.

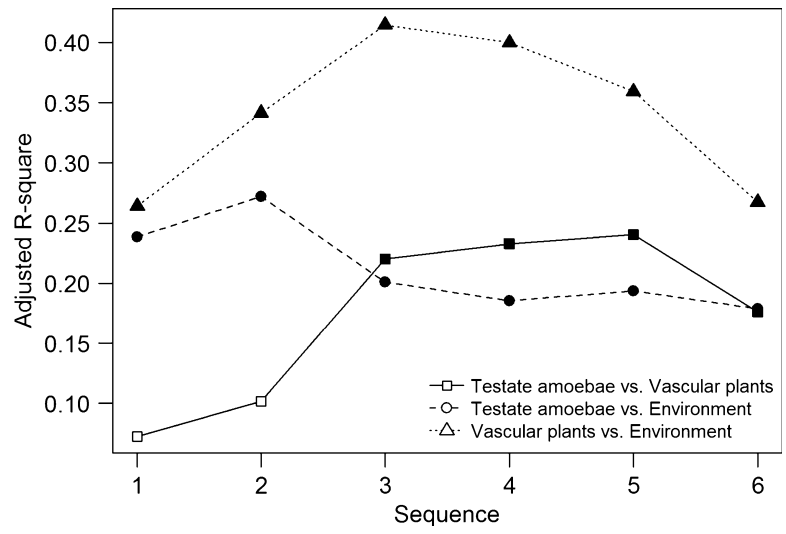

Fig. 6. Moving-window redundancy analysis of the causal relationships between testate amoebae, vascular plants and soil variables along the McCarty Fjord chronosequence, Kenai Fjords, Alaska, USA. Three variables were selected for each biotic group: moisture regime, soil zinc content and percentage cover of rock for the testate amoeba community and depth of soil organics, soil $\mathrm{pH}$ and percentage cover of bare soil for the vascular plant community. The horizontal axis indicates the position of the moving window over which the explained variation was calculated along the chronosequence: 1 : sites 2-11, 2: sites 3-12, .. 6: sites 7-16. Significant relationships are pointed out by solid symbols $(P<0.05)$.

This pattern suggests that above- and below-ground links between these two groups are generally not species specific. Rather, the nature of the plant-testate amoeba link may be governed by the quantitative and qualitative inputs of soil carbon and secondary metabolites produced by vascular plants that relate more to plant functional types and chemically similar groups (e.g. N-fixers, ericoids, grasses) than to species number or identity. The greater influence of plant function relative to plant identity on soil organisms has been shown in several field experiments (Tilman, Lehman \& Thompson 1997; Ledeganck, Nijs \& Beyens 2003; Zak et al. 2003; De Deyn et al. 2004b).

While vascular plant and testate amoeba Shannon diversity patterns are correlated, vascular plant species richness is usually higher than that of testate amoebae, especially on the older terrains. The larger species pool of vascular plants with variable dispersal capabilities likely results in a more prolonged addition of new propagules and thus an increase in species richness beyond the early seral terrains. Testate amoebae are able to disperse passively (predominantly by wind or animals) or actively (by direct migration from adjacent soils) to primary substrates where they can establish founding populations in small pockets of organic material (Wanner \& Dunger 2001). This comparatively smaller pool of founders is exposed to a reduced range of environmental conditions during the founders' short lives and they are able to encyst when conditions exceed their biophysical tolerances (Foissner 1987).

RELATIONSHIPS BETWEEN BIOTIC COMMUNITIES AND SITE VARIABLES

The structure of both vascular plant and testate amoeba communities are principally explained by bedrock type and 
moisture regime as well as other site variables (bare soil and percentage cover of rock, respectively). In addition, the vegetation data are related to successional variables (i.e. the chronosequence), while the testate amoeba data are also explained by a soil chemical variable (zinc content).

The vascular plant communities are generally organized in three groups corresponding to their successional order, with distance to the glacier almost perfectly correlated to axis 1 . By contrast, for testate amoebae the strongest correlation is with moisture regime, and the sites are not strictly organized in successional order.

Similar to other proglacial chronosequences (Matthews 1992), site age is the strongest single organizing variable for plant communities. Along the McCarty Fjord chronosequence, site age is paralleled by a suite of biological, physical and chemical soil development attributes. Because this and other chronosequence studies substitute distance from the glacier for time since deglaciation, the relative influences of time and soil development are not easily separated.

Moisture regime was not predictably related to site age and therefore its relative influence on communities can be separated from that of the time since deglaciation. Moisture regime exhibited a strong relationship with testate amoebae, in agreement with its importance in controlling testate amoeba community structure and density across habitats and with successional age (Lousier 1974; Mitchell, Charman \& Warner 2008). The correlation between moisture regime and vascular plants was weaker, illustrating that other factors related to succession play a more important role in shaping plant communities along the sequence.

Bedrock type emerged as a significant variable explaining both the vegetation and testate amoeba data. This agrees with the well-documented effect of bedrock type on soil characteristics, which in turn influences both vegetation composition (Gobat, Aragno \& Matthey 2004) and testate amoeba communities (Bonnet 1961, 1964).

Zinc is an essential element in the metabolism of all organisms and has been shown to be much less toxic to soil protozoa than other heavy metals such as lead, cadmium or copper (Diaz, Martin-Gonzalez \& Gutierrez 2006; Nguyen-Viet et al. 2007). Zn concentrations ranged from 7 to 212 p.p.m. and were highest at sites 12 (112 p.p.m.), 15 and 16 (>150 p.p.m.), while in all other sites the concentrations were below 75 p.p.m. and below 10 p.p.m. in the first two sites ( 2 and 3 ). At these concentrations $\mathrm{Zn}$ is unlikely to have any toxicity effect and it is unclear if $\mathrm{Zn}$ concentrations influence testate amoeba species indirectly through prey composition availability or if this variable is correlated with other, unmeasured variables.

\section{COMPARISON OF COMMUNITY STRUCTURES}

Recent experimental evidence suggests that biotic interactions between above-ground and below-ground organisms may dampen the effect of abiotic factors on plant dominance (De Deyn, Raaijmakers \& Van der Putten 2004a). Our data from a natural primary succession study supports this idea. In the MFA, testate amoebae and vascular plants were more strongly correlated to each other than to soil physical or chemical variables, or to location variables. Correlations were lower, yet significant, between the physical and location variables in relation to the biological communities.

Contrary to our third hypothesis, the dependence of the testate amoeba community on soil conditions tended to decline slightly after the early successional stages. We expected that the variance explained in testate amoeba communities due to soil conditions would increase in succession as a result the older sites being exposed to all potential colonizing taxa (while recent sites would be a more random assemblage) and therefore community-environmental patterns would be more detectable. Our results may be explained by high dispersal rates (Finlay 2002) and fast generation times (Schönborn 1992) in testate amoebae, where even the recent sites are saturated with the majority of potential taxa.

The plant community, however, had an increase in variance explained by the environmental variables at intermediate aged sites, with a decline in older sites. This pattern may be explained by early successional plants generally having greater amplitude in environmental tolerance, while plants from older successional sites represent an increase in environmental habitat and resource specialization (Bazzaz 1979; Parrish \& Bazzaz 1982). These results partially support our prediction of a decline in plant-environment association later in succession due to an increase in species turnover as vegetation cover increases, and associated increase in biotic interactions, which reduces the relative influence of abiotic factors.

In agreement with our fourth hypothesis, the moving-window analysis revealed an increasingly tight coupling of plant and testate amoeba community structures over successional time. This increase in above-ground and below-ground coupling may relate to a greater frequency and specificity of plant-testate amoeba interactions at high diversities (Kowalchuk et al. 2002) and a transition from allogenic- to autogenicdriven succession (Matthews 1992). Assuming that the sites included in this chronosequence represent true primary succession and that all pertinent site variables were measured, the strong plant-testate amoeba covariation indicates that interactions between above-ground and below-ground biota exert great influence on ecosystem development. Site variables are secondarily important to above-ground-below-ground community succession in so far that the breakdown of mineral material and the accumulation of organic matter over time produce the environment through which plants, microbes and testate amoebae interact. A stronger correlation between biotic groups would have been expected in the case of two clearly linked groups of organisms such as vascular plants and mycorrhizal fungi, but it was not expected for two groups of organisms with no direct trophic link.

The link between testate amoebae and vascular plants may, however, be stronger than generally acknowledged: experiments testing the links between plant and protozoan communities suggest the interaction between the groups is reciprocal; manipulation of one group often produces a response in the other, and this interaction is mediated by bacteria and fungi (Clarholm 1985; Jentschke et al. 1995; Ledeganck, Nijs \& 
Beyens 2003). Increase in plant functional diversity has been shown to promote a proportional increase in testate amoeba species number and abundance (Ledeganck, Nijs \& Beyens 2003). Ledeganck, Nijs \& Beyens (2003) interpreted this pattern as an effect of the hypothesized higher biomass or diversity of bacteria in more functionally diverse plant communities. Complementary studies show that increases in microbial functional diversity promote plant uptake of $\mathrm{N}$ (Clarholm 1985) and increase root growth and branching (Jentschke et al. 1995) through the grazing activity of protozoa on bacteria and the subsequent release of mineralized $\mathrm{N}$ to plants. Testate amoebae diversity patterns shown in this study are similar to those documented for microbes along other plant successional sequences and thus provide additional support for a relationship between plants and microbes over time (Tscherko et al. 2003; Nemergut et al. 2007).

Microbial heterotrophic producers (i.e. bacteria and fungi producing biomass from dissolved organic carbon) are present at all stages of primary succession (Sigler \& Zeyer 2002). Microbe community composition and structure change across successional gradients (Ohtonen et al. 1999) and provide mutual influences on the diversity of both plant and protozoan communities (Ledeganck, Nijs \& Beyens 2003). Protozoa are identified as the 'missing link' between plant and microbial heterotrophic producers because they connect plants and protozoa directly via the microbial loop (Clarholm 1985). We propose that the succession of plant and testate amoeba communities along the McCarty Fjord chronosequence is influenced by: (i) an increasing presence of microbial heterotrophic producers, (ii) a transition from bacteria-dominated, fast and leaky nutrient cycles to fungal-dominated, slow and conservative nutrient cycling (Bardgett et al. 2005), and (iii) frequency of interactions among species of plants, microbes and testate amoebae.

More experimental studies to evaluate the potential mechanisms and relative importance of various ecological interactions (such as variation in carbon quality and secondary plant metabolites, and microbial-mediated mineralization of soil nutrients) between vascular plants and protozoa are warranted. Additionally, we recommend combining soil fungal, protozoan and bacterial communities and soil functions such as respiration or enzymatic activity in future studies of aboveand below-ground succession (for component studies see: Kaufmann 2001; Jumpponen, Trappe \& Cazares 2002; Sigler \& Zeyer 2002; Hodkinson, Coulson \& Webb 2003; Tscherko et al. 2003; Bardgett \& Walker 2004; Hodkinson, Coulson \& Webb 2004; Nemergut et al. 2007). Such comprehensive studies including all major functional groups of organisms and including groups with clear trophic linkages and others with indirect linkages (see: Clarholm 1985; Ledeganck, Nijs \& Beyens 2003; Zak et al. 2003; De Deyn et al. 2004b) are invaluable in understanding how different communities and processes are interconnected in primary succession.

\section{Conclusion}

The relationships between vascular plant and testate amoeba communities evidenced in this study provide additional sup- port for the importance of interactions between above-ground and below-ground biota to ecosystem function. Determining the mechanism of the above-ground-below-ground linkage was beyond the scope of this study, but is inferred to be driven by the quantity and quality of plant carbon inputs, plant secondary metabolites and the variety of mineralized nutrients made available by a succession of heterotrophic soil organisms. The most surprising result is that abiotic site variables in our analyses became less important while other biotic communities became more important in describing above-ground and below-ground community structure across the chronosequence. Replication of this approach in other successional contexts and with greater sampling intensity will be essential in evaluating how universal the transition in relative importance from abiotic to biotic variables is in above- and below-ground community assembly.

\section{Acknowledgements}

Jess Grunblatt, Beth Koltun, Michelle Sturdy, Susan Klein and Keith Boggs provided assistance in the field. The University of Alaska Fairbanks Soils Laboratory at the Palmer Research Center and Laurie Wilson provided lab space and time for chemical soils analysis. Kim Peterson and Keith Boggs offered considerable help in the experimental design and with previous drafts. The National Park Service, Alaska Support Office and Alaska Natural Heritage Program, UAA, provided funding and logistical help. Funding to E.A.D.M. by Swiss NSF project no. 205321- 109709/1, and CCES projects RECORD and BigLink is acknowledged. We thank Pierre Legendre and anonymous referees for their fruitful comments and Andrea Baier for editing the manuscript.

\section{References}

Adl, M.S. \& Gupta, V.V.S.R. (2006) Protists in soil ecology and forest nutrient cycling. Canadian Journal of Forest Research, 36, 1805-1817.

Aoki, Y., Hoshino, M. \& Matsubara, T. (2007) Silica and testate amoebae in a soil under pine-oak forest. Geoderma, 142, 29-35.

Bardgett, R.D. \& Walker, L.R. (2004) Impact of coloniser plant species on the development of decomposer microbial communities following deglaciation. Soil Biology \& Biochemistry, 36, 555-559.

Bardgett, R.D., Bowman, W.D., Kaufmann, R. \& Schmidt, S.K. (2005) A temporal approach to linking aboveground and belowground ecology. Trends in Ecology \& Evolution, 20, 634-641.

Bazzaz, F.A. (1979) The physiological ecology of plant succession. Annual Review of Ecology and Systematics, 10, 351-371.

Bonkowski, M. (2004) Protozoa and plant growth: the microbial loop in soil revisited. New Phytologist, 162, 617-631.

Bonnet, L. (1961) Les thécamobiens, indicateurs pédologiques, et la notion de climax. Bulletin de la Société d'Histoire Naturelle de Toulouse, 96, 80-86.

Bonnet, L. (1964) Le peuplement thécamobiens des sols. Revue d'Écologie et de Biologie du Sol, 1, 123-408.

Bradley, D.C., Kusky, T.M., Haeussler, P.J., Karl, S.M. \& Donley, D.T. (1999) Geologic map of the Seldovia quadrangle, south-central Alaska: USGS Open-File Report OFR 99-18B

Cain, M.L., Milligan, B.G. \& Strand, A.E. (2000) Long-distance seed dispersal in plants. American Journal of Botany, 87, 1217-1227.

Clarholm, M. (1985) Interactions of bacteria, protozoa and plants leading to mineralization of soil nitrogen. Soil Biology \& Biochemistry, 17, 181-187.

Clarholm, M. (2005) Soil protozoa: an under-researched microbial group gaining momentum. Soil Biology and Biochemistry, 37, 811-817.

Connor, E.F. \& Simberloff, D. (1979) The assembly of species communities chance or competition. Ecology, 60, 1132-1140.

Crowell, A.L. \& Mann, D.H. (1995) Glacier Extent and Margins - 19th Century - Kenai Fjords National Park, Vector Digital Data, 1:63,360, Created for the Alaska. U.S. Geological Survey, Geologic Division.

Cutler, N.A., Belyea, L.R. \& Dugmore, A.J. (2008) The spatiotemporal dynamics of a primary succession. Journal of Ecology, 96, 231-246.

De Deyn, G.B. \& Van der Putten, W.H. (2005) Linking aboveground and belowground diversity. Trends in Ecology \& Evolution, 20, 625-633. 
De Deyn, G.B., Raaijmakers, C.E., Zoomer, H.R., Berg, M.P., de Ruiter, P.C., Verhoef, H.A., Bezemer, T.M. \& van der Putten, W.H. (2003) Soil invertebrate fauna enhances grassland succession and diversity. Nature, 422, $711-713$.

De Deyn, G.B., Raaijmakers, C.E. \& Van der Putten, W.H. (2004a) Plant community development is affected by nutrients and soil biota. Journal of Ecology, 92, 824-834.

De Deyn, G.B., Raaijmakers, C.E., van Ruijven, J., Berendse, F. \& van der Putten, W.H. (2004b) Plant species identity and diversity effects on different trophic levels of nematodes in the soil food web. Oikos, 106, 576-586.

Diaz, S., Martin-Gonzalez, A. \& Gutierrez, J.C. (2006) Evaluation of heavy metal acute toxicity and bioaccumulation in soil ciliated protozoa. Environment International, 32, 711-717.

Dray, S., Chessel, D. \& Thioulouse, J. (2003) Co-inertia analysis and the linking of ecological data tables. Ecology, 84, 3078-3089.

Environmental Systems Research Institute Inc. (1998) Glaciers, 1 to 1,000,000, vector digital data, created for the Alaska Department of Natural Resources, Land Records Information Section. Available at http://dnr.alaska.gov/ SpatialUtility/SUC? $\mathrm{cmd}=$ extract\&layerid $=27$.

Environmental Systems Research Institute Inc. (2006) ArcGIS 9, ArcMap Version 9.2, A Software Program for the Spatial Analysis of Geographic Data. Environmental Systems Research Institute Inc, Redlands, California, USA.

Escofier, B. \& Pagès, J. (1994) Multiple factor analysis (AFMULT package). Computational Statistics and Data Analysis, 18, 121-140.

Fastie, C.L. (1995) Causes and ecosystem consequences of multiple pathways of primary succession at Glacier Bay, Alaska. Ecology, 76, 1899-1916.

Finlay, B.J. (2002) Global dispersal of free-living microbial eukaryote species. Science, 296, 1061-1063.

Flagstad, L. (2007) A comparison of aboveground and belowground community succession along a proglacial chronosequence in Kenai Fjords, Alaska. MSc Thesis, University of Alaska, Anchorage.

Foissner, W. (1987) Soil protozoa: fundamental problems, ecological significance, adaptation in ciliates and testaceans, bioindicators, and guide to the literature. Progress in Protozoology, 2, 69-212.

Foissner, W. (2007) Protist diversity and distribution: some basic considerations. Biodiversity and Conservation, 17, 235-242.

Gobat, J.M., Aragno, M. \& Matthey, W. (2004) The Living Soil. Fundamental of Soil Science and Soil Biology. Science Publishers, Enfield (NH), USA.

Gough, L., Shaver, G.R., Carroll, J., Royer, D.L. \& Laundre, J.A. (2000) Vascular plant species richness in Alaskan arctic tundra: the importance of soil pH. Journal of Ecology, 88, 54-66.

Harrison, K.A., Bol, R. \& Bardgett, R.D. (2007) Preferences for different nitrogen forms by coexisting plant species and soil microbes. Ecology, 88, 989-999.

Hendon, D. \& Charman, D.J. (1997) The preparation of testate amoebae (Protozoa: Rhizopoda) samples from peat. Holocene, 7, 199-205.

Hill, M.O. (1973) Diversity and evenness - unifying notation and its consequences. Ecology, 54, 427-432.

Hodkinson, I.D., Coulson, S.J. \& Webb, N.R. (2003) Community assembly along proglacial chronosequences in the high Arctic: vegetation and soil development in north-west Svalbard. Journal of Ecology, 91, 651-663.

Hodkinson, I.D., Coulson, S.J. \& Webb, N.R. (2004) Invertebrate community assembly along proglacial chronosequences in the high Arctic. Journal of Animal Ecology, 73, 556-568.

Hooper, D.U., Bignell, D.E., Brown, V.K., Brussaard, L., Dangerfield, J.M., Wall, D.H. et al. (2000) Interactions between aboveground and belowground biodiversity in terrestrial ecosystems: patterns, mechanisms, and feedbacks. BioScience, 50, 1049-1061.

Hubbell, S.P. (2001) The Unified Neutral Theory of Biodiversity and Biogeography. Princeton University Press, Princeton, New Jersey, USA

Husson, F., Josse, J., Lê, S. \& Mazet, J. (2009) FactoMineR: Factor Analysis and Data Mining with $R$. $R$ package, version 1.12. Available at: http:/ CRAN.R-project.org $/$ package $=$ FactoMineR

Huston, M. \& Smith, T. (1987) Plant succession - life-history and competition American Naturalist, 130, 168-198.

Jentschke, G., Bonkowski, M., Godbold, D.L. \& Scheu, S. (1995) Soil protozoa and forest tree growth - non-nutritional effects and interaction with mycorrhizae. Biology and Fertility of Soils, 20, 263-269.

Jones, C. \& del Moral, R. (2009) Dispersal and establishment both limit colonization during primary succession on a glacier foreland. Plant Ecology, 204 217-230.

Josse, J., Pagès, J. \& Husson, F. (2008) Testing the significance of the RV coefficient. Computational Statistics and Data Analysis, 53, 82-91.

Jumpponen, A., Trappe, J.M. \& Cazares, E. (2002) Occurrence of ectomycorrhizal fungi on the forefront of retreating Lyman Glacier (Washington, USA) in relation to time since deglaciation. Mycorrhiza, 12, 43-49.
Kardol, P., Bezemer, T.M. \& van der Putten, W.H. (2006) Temporal variation in plant-soil feedback controls succession. Ecology Letters, 9, 1080-1088.

Kardol, P., Bezemer, T.M., van der Wal, A. \& van der Putten, W.H. (2005) Successional trajectories of soil nematode and plant communities in a chronosequence of ex-arable lands. Biological Conservation, 126, 317-327.

Kaufmann, R. (2001) Invertebrate succession on an alpine glacier foreland. Ecology, 82, 2261-2278.

Kent, M., Gill, W.J., Weaver, R.E. \& Armitage, R.P. (1997) Landscape and plant community boundaries in biogeography. Progress in Physical Geography, 21, 315-353.

Kowalchuk, G.A., Buma, D.S., de Boer, W., Klinkhamer, P.G.L. \& van Veen, J.A. (2002) Effects of above-ground plant species composition and diversity on the diversity of soil-borne microorganisms. Antonie van Leeuwenhoek, 81, 509-520.

Lamentowicz, M., Lamentowicz, Ł., van der Knaap, W.O., Gạbka, M. \& Mitchell, E.A.D. (2010) Contrasting species-environment relationships in communities of testate amoebae, bryophytes and vascular plants along the Fen-Bog gradient. Microbial Ecology, 56, 499-510.

Lê, S., Josse, J. \& Husson, F. (2008) FactoMineR: an R package for multivariate analysis. Journal of Statistical Software, 25, 1. Available at: http:// www.jstatsoft.org/.

Ledeganck, P., Nijs, I. \& Beyens, L. (2003) Plant functional group diversity promotes soil protist diversity. Protist, 154, 239-249.

Legendre, P. \& Gallagher, E.D. (2001) Ecologically meaningful transformations for ordination of species data. Oecologia, 129, 271-280.

Legendre, P. \& Legendre, L. (1998) Numerical Ecology: Second English Edition. Elsevier, Amsterdam, The Netherlands.

Legendre, P., Borcard, D. \& Peres-Neto, P.R. (2005) Analyzing beta diversity: partitioning the spatial variation of community composition data. Ecological Monographs, 75, 435-450.

Lousier, J.D. (1974) Response of soil testacea to soil moisture fluctuations. Soil Biology \& Biochemistry, 6, 235-239.

Mahaming, A.R., Mills, A.A.S. \& Adl, S.M. (2009) Soil community changes during secondary succession to naturalized grasslands. Applied Soil Ecology, 41, 137-147.

Matthews, J.A. (1992) The Ecology of Recently Deglaciated Terrain. Cambridge University Press, Cambridge, UK.

Matthews, J.A. \& Whittaker, R.J. (1987) Vegetation succession on the Storbreen Glacier foreland, Jotunheimen, Norway: a review. Arctic and Alpine Research, 19, 385-395.

Mitchell, E.A.D., Charman, D.J. \& Warner, B.G. (2008) Testate amoebae analysis in ecological and paleoecological studies of wetlands: past, present and future. Biodiversity and Conservation, 17, 2115-2137.

del Moral, R. \& Bliss, L.C. (1993) Mechanisms of primary succession: insights resulting from the eruption of Mount St. Helens. Advances in Ecological Research, 24, 1-66.

Nathan, R. \& Muller-Landau, H.C. (2000) Spatial patterns of seed dispersal, their determinants and consequences for recruitment. Trends in Ecology and Evolution, 15, 278-285.

National Park Service (2002) Compressed Kenai Fjords National Park Satellite Imagery Mosaic bands 4,3,2, raster digital data, created for National Park Service, Alaska Regional Office. Data file avilable at http://nrdata.nps.gov/ kefj/kefjdata/kefj432.zip; metadata: http://nrdata.nps.gov/kefj/kefjdata/kefj 432.xml.

Nemergut, D.R., Anderson, S.P., Cleveland, C.C., Martin, A.P., Miller, A.E., Seimon, A. \& Schmidt, S.K. (2007) Microbial community succession in an unvegetated, recently deglaciated soil. Microbial Ecology, 53, 110-122.

Nguyen-Viet, H., Bernard, N., Mitchell, E.A.D., Cortet, J., Badot, P.-M. \& Gilbert, D. (2007) Relationship between testate amoeba (Protist) communities and atmospheric heavy metals accumulated in Barbula indica (Bryophyta) in Vietnam. Microbial Ecology, 53, 53-65.

Odum, E.P. (1971) Fundamentals of Ecology. W. B. Saunders Co., Philadelphia/London/Toronto.

Ohtonen, R., Fritze, H., Pennanen, T., Jumpponen, A. \& Trappe, J. (1999) Ecosystem properties and microbial community changes in primary succession on a glacier forefront. Oecologia, 119, 239-246.

Oksanen, J., Blanchet, G., Kindt, R., Legendre, P., O'Hara, R.G., Simpson, G.L., Solymos, P., Stevens, M.H.H. \& Wagner, H. (2010) Vegan: community ecology package. $\mathrm{R}$ package version 1.17-1. Available at: http:// CRAN.R-project.org $/$ package $=$ vegan.

Parrish, J.A.D. \& Bazzaz, F.A. (1982) Niche responses of early and late successional tree seedlings on three resource gradients. Bulletin of the Torrey Botanical Club, 109, 451-456. 
Post, A. (1980) Preliminary bathymetry of McCarty Fjord and neoglacial changes of McCarty Glacier, Alaska. USGS Open-file Report 80-424.

Prendergast, J.R., Quinn, R.M., Lawton, J.H., Eversham, B.C. \& Gibbons, D.W. (1993) Rare species, the coincidence of diversity hotspots and conservation strategies. Nature, $\mathbf{3 6 5}, 335-337$.

R Development Core Team (2009) R: a language and environment for statistical computing. R Foundation for Statistical Computing, Vienna, Austria Available at: http://www.R-project.org.

Reiners, W.A., Worley, I.A. \& Lawrence, D.B. (1971) Plant diversity in a chronosequence at Glacier Bay, Alaska. Ecology, 52, 55-69.

Reynolds, H.L., Packer, A., Bever, J.D. \& Clay, K. (2003) Grassroots ecology: plant-microbe-soil interactions as drivers of plant community structure and dynamics. Ecology, 84, 2281-2291.

Robert, P. \& Escoufier, Y. (1976) A unifying tool for linear multivariate statistical methods: the RV-coefficient. Applied Statistics, 25, 257-265.

Scheu, S. \& Schulz, E. (1996) Secondary succession, soil formation and development of a diverse community of oribatids and saprophagous soil macro-invertebrates. Biodiversity and Conservation, 5, 235-250.

Schönborn, W. (1992) The role of protozoan communities in freshwater and soil ecosystems. Acta protozoologica, 31, 11-18.

Schröter, D., Wolters, V. \& De Ruiter, P.C. (2003) C and N mineralisation in the decomposer food webs of a European forest transect. Oikos, 102, 294-308.

Sigler, W.V. \& Zeyer, J. (2002) Microbial diversity and activity along the forefields of two receding glaciers. Microbial Ecology, 43, 397-407.

Tilman, D., Lehman, C.L. \& Thompson, K.T. (1997) Plant diversity and ecosystem productivity: theoretical considerations. Proceedings of the National Academy of Sciences, 94, 1857-1861.

Tscherko, D., Rustemeier, J., Richter, A., Wanek, W. \& Kandeler, E. (2003) Functional diversity of the soil microflora in primary succession across two glacier forelands in the Central Alps. European Journal of Soil Science, $\mathbf{5 4}$ 685-696.

Tysdal, R.G. \& Case, J.E. (1979) Geologic Map of the Seward and Blying Sound quadrangles, southern Alaska USGS Miscellaneous Investigation Series Map I-1150, scale 1:250,000.

Viereck, L.A., Dyrness, C.T., Batten, A.R. \& Wenzlick, K.J. (1992) The Alaska Vegetation Classification. General Technical Report, PNW-GTR-286. US Department of Agriculture, Forest Service, Pacific Northwest Research Station, Oregon, USA.

Wanner, M. \& Dunger, W. (2001) Biological activity of soils from reclaimed open-cast coal mining areas in Upper Lusatia using testate amoebae (protists) as indicators. Ecological Engineering, 17, 323-330.

Wanner, M. \& Xylander, W.E.R. (2005) Biodiversity development of terrestrial testate amoebae: is there any succession at all? Biology and Fertility of Soils, 41, 428-438
Wanner, M., Elmer, M., Kazda, M. \& Xylander, W.E.R. (2008) Community assembly of terrestrial testate amoebae: How is the very first beginning characterized? Microbial Ecology, 56, 43-54.

Wardle, D.A. (2002) Communities and Ecosystems: Linking the Aboveground and Belowground Components. Princeton University Press, Princeton, New Jersey, USA.

Wardle, D.A., Walker, L.R. \& Bardgett, R.D. (2004) Ecosystem properties and forest decline in contrasting long-term chronosequences. Science, 305, 509513

Weiher, E. \& Keddy, P.A. (1999) Relative abundance and evenness patterns along diversity and biomass gradients. Oikos, $87,355-361$.

Wiles, G.C. \& Calkin, P.E. (1993) Neoglacial fluctuations and sedimentation of an iceberg-calving glacier resolved with tree-rings (Kenai Fjords National Park, Alaska). Quaternary International, 18, 35-42.

Wiles, G.C. \& Calkin, P.E. (1994) Late Holocene, high-resolution glacial chronologies and climate, Kenai Mountains, Alaska. Geological Society of America Bulletin, 106, 281-303.

Wilkinson, D.M. (2008) Testate amoebae and nutrient cycling: peering into the black box of soil ecology. Trends in Ecology \& Evolution, 23, 596-599.

Zak, R., Holms, W.E., White, D.C., Peacock, A.D. \& Tilman, D. (2003) Plant diversity, soil microbial communities, and ecosystem function: are there any links? Ecology, 84, 2042-2050.

Received 3 July 2009; accepted 15 June 2010

Handling Editor: Roy Turkington

\section{Supporting Information}

Additional supporting information may be found in the online version of this article:

Appendix S1. Description of plant community types.

Appendix S2. Description of testate amoeba community types.

As a service to our authors and readers, this journal provides supporting information supplied by the authors. Such materials may be re-organized for online delivery, but are not copy-edited or typeset. Technical support issues arising from supporting information (other than missing files) should be addressed to the authors. 